Research Article

\title{
Biological Resistance and Application Properties of Particleboards Containing Nano-Zinc Oxide
}

\author{
Ladislav Reinprecht $\mathbb{D}^{\mathbb{D}}$, Ján Iždinský, and Zuzana Vidholdová \\ Faculty of Wood Sciences and Technology, Technical University in Zvolen, T. G. Masaryka 24, 96053 Zvolen, Slovakia \\ Correspondence should be addressed to Ladislav Reinprecht; reinprecht@tuzvo.sk
}

Received 18 January 2018; Revised 27 March 2018; Accepted 4 April 2018; Published 22 April 2018

Academic Editor: Mikhael Bechelany

Copyright (C) 2018 Ladislav Reinprecht et al. This is an open access article distributed under the Creative Commons Attribution License, which permits unrestricted use, distribution, and reproduction in any medium, provided the original work is properly cited.

\begin{abstract}
Special particleboards (PBs) proposed for kitchens, bathrooms, hospitals, and some other specific products for interiors should have a sufficient resistance against bacteria, molds, and decaying fungi. This work deals about effects of zinc oxide nanoparticles (nano- $\mathrm{ZnO}$ ) added into melamine-urea-formaldehyde (MUF) glue in the amounts of $0,2,6,12$, or 24\% wt. on selected biological, moisture, and strength properties of laboratory-produced one-layer PBs. The nano-ZnO-treated PBs had a higher biological resistance: (1) against the Gram-positive bacterium Staphylococcus aureus by up to ca. $70 \%$ and the Gram-negative bacterium Escherichia coli by up to $50 \%$, since their bacterial activities at using 1.0 McFarland bacterial inoculum decreased from $0.38-0.40$ by up to $0.12-0.19 \times 10^{8} \mathrm{CFU} / \mathrm{ml}$; (2) against the molds Penicillium brevicompactum and Aspergillus niger by up to ca. 50-63\%, since their growth intensities (0-4) on the top surfaces of treated PBs decreased according to a modified EN 15457 from 2.33-2.67 by up to 1.17-1.0; (3) against the brown-rot fungus Coniophora puteana by up to $85.7 \%$, since their weight losses reduced according to a modified ENV 12038 from $17.4 \%$ by up to $2.5 \%$. The presence of nano- $\mathrm{ZnO}$ in $\mathrm{PBs}$ uninfluenced their swelling, water absorption, and bending strength; however, it decreased their internal bond strength by up to $38.8 \%$.
\end{abstract}

\section{Introduction}

According to Imamura [1] and more other researches (e.g., [2-4]), the biological resistance of particleboards (PBs) - and similar other wood composites, that is, fibreboards, cardboards, oriented strand boards, plywood, laminated veneer lumbers, and glulam-against bacteria, molds, decaying fungi, and insects is in a defined environment affected first of all by (1) the used wood species, (2) the size and shape of wood particles, (3) the type and amount of organic glue or inorganic cement adhesive and used additives including biocides, and (4) the dimension, surface roughness, and other geometric characteristics of the PB and products made from this material. By the abovementioned factors (1) to (4) can also be influenced application properties of PBs, for example, their swelling and strength [4-8].

The common types of PBs produced for a dry inner environment, that is, for the use classes 1 and 2 [9] - it means unlike water-resistant glulam or plywood suitable for the use classes 3 and 4 [9] - must not be resistant to water or to bacterial and fungal attacks. However, the need for a higher biological resistance of PBs in interiors occurs when they have to withstand a shorter-time impact of additional wetting when achieving a moisture content above $20 \%$. So, in the high bacterial, mold, and decay risk environments, for example, if creation of condensate water cannot be excluded, the PBs should have an increased biological durability. It can be achieved (1) by using acceptable-environmentally friendly and technologically suitable and applicable biocides [10-14] and (2) by using particles either from more durable wood species [15] or from cuttings and other residues of thermally and chemically modified woods having a higher resistance to pests as natural woods.

The increase of the biological resistance of PBs against bacteria, molds, and decaying fungi can be realised (1) by their postmanufacture surface treatment (PMST), for example, by lamination with traditional melamine resinimpregnated papers [16], by lamination with impregnated 
papers containing biocides $[17,18]$, by painting with acrylic, epoxy, or other coatings unmodified or modified without biocides [19], and by fumigation with creation of stable biocides, for example, with trimethyl borate which is transformed to boric acid [20] or with supercritical carbon dioxide fluid (SCF-CO $\mathrm{CO}_{2}$ ) of organic biocides [21], and (2) by the in-process treatment (IPT) applying biocides directly in the production process, for example, by impregnation of wood particles with thermostable inorganic, heterocyclic, or other organic fungicides [2, 22], by using special bioactive glues, by addition of biocides into glues [23, 24], by addition of biocides when applying a glue, when layering wood particles, or during pressing of particleboards. A more effective biological protection of PBs can usually be achieved in those cases where the biocides are applied by the IPTs. However, when using such direct treatments, some application properties of PBs can more rapidly be worsened.

For interiors, the general recommendation applies that using environmental-harmful and health-harmful substances, including more types of wood preservatives, should be maximally limited. Therefore, in situations, when a treatment of wood or wooden composites with biocides is needed by EN 460 [25], these substances should be applied only on the basis of valid and regularly updated regulations for biocidal products by ECHA $[26,27]$.

Nano-ZnO can be applied for interiors. Due to a reduced size of particles, it is evidently a more effective biocide compared to classical $\mathrm{ZnO}$ powders having larger-sized particles [28-30]. Nano- $\mathrm{ZnO}$ is able to interact with bacteria, fungi, insects, and other pests, either with the surfaces of a living cell or after penetration to the living cell with its core [31]. Several authors described a biological activity of $\mathrm{ZnO}$ nanoparticles against the Gram-positive and Gramnegative bacteria [32-35], various species of wood-decaying fungi $[36,37]$, usually more against the white-rot fungi as against the brown-rot ones [38], and molds [39]. For example, in our previous experiments, it was found that zinc oxide nanoparticles, used as $0.1-1 \%$ dispersions for treatment of lime and maple woods, suppressed the decay activity of the white-rot fungus Trametes versicolor by up to $56.3 \%$ and the brown-rot fungus Coniophora puteana by up to $39.3 \%$ [40], which on the top surfaces of these wood species partly reduced the activity of the molds Aspergillus niger and Penicillium brevicompactum [41].

The aim of this study was a complete search on selected bactericidal, fungicidal, moisture, and strength properties of nano- $\mathrm{ZnO}$-treated PBs prepared by the IPT method, when zinc oxide nanoparticles were added into melamineurea-formaldehyde glue.

\section{Experimental}

2.1. Treatment of MUF Glue with Nano-Zinc Oxide. The basic melamine-urea-formaldehyde (MUF) glue with a molar ratio of formaldehyde and urea of $1: 1.15$ and with $20 \%$ wt. addition of melamine was prepared in Kronospan Bučina DDD Co. Ltd., Zvolen, Slovakia. Its hardener, the "catalyst of condensation," was ammonium nitrate $\left(\mathrm{NH}_{4} \mathrm{NO}_{3}\right)$, and it
TABle 1: Curing times of MUF glues treated with zinc oxide nanoparticles determined at $100^{\circ} \mathrm{C}$.

\begin{tabular}{lccccc}
\hline \multirow{2}{*}{ MUF glue } & \multicolumn{5}{c}{ Addition of nano-ZnO (\% wt.) } \\
& 0 & 2 & 6 & 12 & 24 \\
\hline Curing time (s) & 198 & 261 & 271 & 317 & 384 \\
\hline
\end{tabular}

was used in the amount of $2.5 \%$ wt. (weight of solid hardener per solid weight of catalysed glue).

The basic MUF glue was treated with zinc oxide nanoparticles (nano-ZnO) (Sigma-Aldrich Co. Ltd., Munich, Germany; $<100 \mathrm{~nm}$ particle size (DLS); $<35 \mathrm{~nm}$ average particle size (APS); 50\% wt. in water) in the amounts of $0,2,6$, 12 , or $24 \%$ wt. (weight of solid nano-ZnO per solid weight of catalysed MUF glue). MUF glues treated with nano-ZnO had maximally 1.94 times prolonged curing time (Table 1). However, the viscosity of all modified MUF glues was constant, that is, $62 \pm 2 \mathrm{~s}$ measured by Ford $4 \mathrm{cup}$ at $20^{\circ} \mathrm{C}$.

2.2. Particleboard Preparation. One-layer particleboards (PBs) with the area size of $360 \mathrm{~mm} \times 360 \mathrm{~mm}$ and the nominal thickness of $16.0 \mathrm{~mm}$ were prepared in laboratories of the Technical University in Zvolen. For their production, these substances were used with recalculation of their parts on the absolute dry mass: (1) 10 parts of wood-chipped particles-9.5 parts of spruce, fir, and pine and 0.5 part of beech and oak-used at 3.5\% moisture content; (2) 1 part of MUF glue- 0.965 part of the basic MUF glue, 0.025 part of the hardener ammonium nitrate, and 0.010 part of paraffin-used in a form of $67 \%$ water solution; and (3) 0 to 0.24 part of nano- $\mathrm{ZnO}$ used in a form of $50 \%$ water nanosuspension. A uniform homogenization of $\mathrm{ZnO}$ nanoparticles in MUF glues was made by continual mixing of modified glues in a laboratory agitator (Diaf, Denmark) until they were applied to the wood particles.

Application of nano-ZnO-modified MUF glues on wood-chipped particles was performed in a laboratory rotary mixing device (VDL-TU Zvolen, Slovakia). Wood particles coated with glues were then loaded into a prepressing form and finally pressed in a laboratory press CBJ 100-11 (TOS Rakovník, Czech Republic). The pressing process was performed according to a three-stage pressing diagram at the maximum temperature of $210^{\circ} \mathrm{C}$, maximum specific pressure of $5.33 \mathrm{MPa}$, and pressing factor of $14 \mathrm{~s}$, which is analogous with preparation of $\mathrm{PBs}$ containing polyethylene terephthalate [42]. Totally 15 PBs were prepared, that is, control and four types treated with nano- $\mathrm{ZnO}$ (3 pieces from each).

2.3. Biological Resistance of Particleboards. The bacterial, mold, and decay tests of PBs were performed on the samples with a reduced thickness of $7.0 \mathrm{~mm}$-achieved by cutting of PBs to their half of the nominal thickness-with the intention to perform all biological tests in Petri dishes with a diameter of $120 \mathrm{~mm}$ and an internal height of $17 \mathrm{~mm}$. Firstly, PB samples were conditioned at 
a temperature of $20 \pm 2^{\circ} \mathrm{C}$ and a relative humidity of $65 \pm$ $2 \%$, achieving their EMC of $12 \pm 1 \%$. Following this, the side and bottom surfaces of $\mathrm{PB}$ samples were 2 times coated with epoxy resin CHS-Epoxy 1200 mixed with hardener P11 (Stachema, Mělník, Czech Republic). Finally, all surfaces of PB samples were sterilized for $1 \mathrm{~h}$ with a UV light radiator.

A previous leaching of $\mathrm{PB}$ samples in distilled water by the Standard EN 84 [43] (or by other leaching methods) was not performed because the laboratory-prepared nano- $\mathrm{ZnO}$ treated PBs contained a partly water unstable MUF glue. It means that these PBs can be recommended only for indoor expositions with an occasional moisture increasing, where the mitigation of nano- $\mathrm{ZnO}$ biocidal effect due to leaching processes is not expected.

2.3.1. Bacterial Test. The resistance test of PBs to bacteria was performed with the Gram-positive bacterium Staphylococcus aureus ATCC-25923 and the Gram-negative bacterium Escherichia coli ATCC-25922.

The top surfaces of the samples with the size of $50 \mathrm{~mm} \times 50 \mathrm{~mm} \times 7 \mathrm{~mm}$ were cleaned with alcohol solution (8.8:1.2 mixture of ethanol and 2-propanol) and inoculated in Petri dishes with a diameter of $120 \mathrm{~mm}$ with $0.1 \mathrm{ml}$ of bacterial suspension. Two types of bacterial suspension were used in the physiological solution, that is, 0.5 and 1.0 of the McFarland scale $\left(1.5 \times 10^{8}\right.$ and $3.0 \times 10^{8} \mathrm{CFU} / \mathrm{ml}$ ). Incubation of bacteria on the top surfaces of the samples was performed at $37^{\circ} \mathrm{C}$ for 48 hours. Afterwards, bacteria were stripped from the top surfaces of PBs using a sterile swab, then taken up in the liquid culture medium for 48 hours, and finally preinoculated from the liquid medium into the sodium chloride diagnostic soil in Petri dishes.

The activity of bacteria on the top surfaces of PBs was assessed indirectly in these diagnostic soils in $\mathrm{CFU} / \mathrm{ml}$.

2.3.2. Mold Test. The mold resistance test of PBs was performed in accordance with a modified Standard EN 15457 [44], that is, using (1) the standard mold Aspergillus niger Tiegh. and also the nonstandard mold Penicillium brevicompactum Dierckx instead of the usually recommended P. purpurogenum, (2) other dimensions of the samples, and (3) other sterilization methods of the samples.

Samples with the size of $40 \mathrm{~mm} \times 20 \mathrm{~mm} \times 7 \mathrm{~mm}$ were at sterile conditions placed into Petri dishes with a diameter of $120 \mathrm{~mm}$ on plastic mats-two tested samples into one dish filled with a 3-4 mm thick layer of the $4.9 \%$ Czapek-Dox agar (HiMedia Ltd., India) - and inoculated with water suspension of mold spores. Incubation of the samples lasted 21 days at a temperature of $24 \pm 2^{\circ} \mathrm{C}$ and a relative humidity of 90-95\%.

The growth intensity of molds on the top surfaces of PBs was assessed by the scale from 0 to 4 , using the following criteria: $0=$ no mold on the surface; $1=$ mold up to $10 \%$; $2=$ mold up to $30 \% ; 3=$ mold up to $50 \%$; and $4=$ mold more than $50 \%$ on the surface.
2.3.3. Decay Test. The decay resistance test of $\mathrm{PBs}$ was carried out according to a modified Standard ENV 12038 [45] with the brown-rot fungus Coniophora puteana (Schumacher ex Fries) Karsten, strain BAM Ebw. 15 using (1) other dimensions and sterilization of the samples and (2) a shorter time of their incubation (6 weeks instead of 16 weeks, as the dimension of the tested samples was smaller compared to that of the standardized ones, $50 \mathrm{~mm} \times$ $50 \mathrm{~mm} \times$ thickness).

Samples with the size of $40 \mathrm{~mm} \times 40 \mathrm{~mm} \times 7 \mathrm{~mm}$ were at sterile conditions placed into Petri dishes with a diameter of $120 \mathrm{~mm}$ on plastic mats under which a fungal mycelium has already grown up-one tested sample and one control sample per dish filled with a 3-4 mm thick layer of the $4.5 \%$ malt agar (HiMedia Ltd., India). Incubation of the samples lasted 6 weeks at a temperature of $24 \pm 2^{\circ} \mathrm{C}$ and a relative humidity of $65-75 \%$.

The decay attack of PB samples was evaluated from their weight losses $(\Delta m)$. For these aims, the samples before and after the decay test were air-conditioned at a temperature of $20 \pm 2^{\circ} \mathrm{C}$ and a relative humidity of $65 \pm 2 \%$, achieving their constant weight with an accuracy of $0.001 \mathrm{~g}$. The weight losses of PBs were determined from their weights in conditioned states before $\left(m_{0}\right)$ and after the fungal attack $\left(m_{\text {fungal attack }}\right)$ by

$$
\Delta m=\frac{m_{0}-m_{\text {fungal attack }}}{m_{0}} \cdot 100(\%) .
$$

2.4. Application Properties of Particleboards. PB samples, having a nominal thickness of $16.0 \mathrm{~mm}$, were used for testing their density, moisture, and strength properties. The thickness swelling (TS) and water absorption (WA) were determined after 2 and 24 hours by the Standard EN 317 [46]. The internal bond (IB) strength, that is, the tensile strength perpendicular to the plane of $\mathrm{PBs}$, was determined by the Standard EN 319 [47], and the bending strength (BS), that is, the modulus of rupture of $\mathrm{PBs}$, was determined by the Standard EN 310 [48]. For both strength analyses, a universal machine TiraTest 2200 (VEB TIW Rauenstein, Germany) was used.

\section{Results and Discussion}

3.1. Biological Resistance of PBs. The nano-ZnO-treated PBs had a better biological resistance against bacterial, mold, and decay attacks compared to the control untreated PB (Table 2).

The activity of the Gram-positive bacterium Staphylococcus aureus on the top surfaces of the nano- $\mathrm{ZnO}$-treated PBs decreased maximally about $70-74 \%$ (Table 2), that is, from 0.19 up to $0.05 \times 10^{8} \mathrm{CFU} / \mathrm{ml}$ at using a $0.5 \mathrm{McF}$ arland scale of bacterial inoculum (SBI), or from 0.40 up to $0.12 \times 10^{8} \mathrm{CFU} / \mathrm{ml}$ at using a $1.0 \mathrm{McF}$ arland SBI. The activity of the Gram-negative bacterium Escherichia coli decreased as well (Table 2), however milder, maximally about 50\% (i.e., from 0.38 up to $0.19 \times 10^{8} \mathrm{CFU} / \mathrm{ml}$ ) at using 1.0 
TABLE 2: Biological resistances of the control PB and the nano-ZnO-treated PBs against two bacteria, two molds, and the brown-rot fungus C. puteana.

\begin{tabular}{|c|c|c|c|c|c|c|c|}
\hline \multirow{3}{*}{$\begin{array}{l}\text { Biocidal properties } \\
\text { of PBs } \\
\text { Nano-ZnO } \\
\text { (\% wt. in MUF glue) }\end{array}$} & \multicolumn{4}{|c|}{ Bacterial activity $\left(10^{8} \mathrm{CFU} / \mathrm{ml}\right)$} & \multicolumn{2}{|c|}{$\begin{array}{l}\text { Growth intensity of the } \\
\text { mold }(0-4)\end{array}$} & \multirow{3}{*}{$\begin{array}{l}\text { Weight } \\
\text { loss (\%) } \\
\text { Coniophora } \\
\text { puteana }\end{array}$} \\
\hline & \multicolumn{2}{|c|}{ Staphylococcus aureus } & \multicolumn{2}{|c|}{ Escherichia coli } & \multirow{2}{*}{$\begin{array}{c}\text { Penicillium } \\
\text { brevicompactum }\end{array}$} & \multirow{2}{*}{$\begin{array}{l}\text { Aspergillus } \\
\text { niger }\end{array}$} & \\
\hline & $0.5^{*}$ & $1.0^{*}$ & $0.5^{*}$ & $1.0^{*}$ & & & \\
\hline 0 & 0.19 & 0.40 & 0.15 & 0.38 & $2.33(0.52)$ & $2.67(0.52)$ & $17.38(2.96)$ \\
\hline 2 & 0.17 & 0.40 & 0.13 & 0.36 & $1.83(0.41)^{\mathrm{d}}$ & $2.00(0.63)^{c}$ & $11.60(0.27)^{\mathrm{a}}$ \\
\hline 6 & 0.13 & 0.31 & 0.15 & 0.34 & $1.33(0.52)^{\mathrm{b}}$ & $2.17(0.41)^{\mathrm{d}}$ & $6.34(0.31)^{\mathrm{a}}$ \\
\hline 12 & 0.12 & 0.23 & 0.14 & 0.24 & $1.33(0.52)^{\mathrm{b}}$ & $1.83(0.41)^{\mathrm{b}}$ & $4.68(1.61)^{\mathrm{a}}$ \\
\hline 24 & 0.05 & 0.12 & 0.12 & 0.19 & $1.17(0.41)^{\mathrm{a}}$ & $1.00(0.00)^{\mathrm{a}}$ & $2.48(1.04)^{\mathrm{a}}$ \\
\hline
\end{tabular}

Note. Mean values: (1) activity of each bacterium from 3 samples, (2) growth intensity of each mold from 6 samples, and (3) decay attack with C. puteana from 6 samples; standard deviations are in parentheses; the Duncan test with levels of significance $\left({ }^{\mathrm{a}}>99.9 \%\right.$, ${ }^{\mathrm{b}}>99 \%$ to $\leq 99.9 \%,{ }^{\mathrm{c}}>95 \%$ to $\leq 99 \%$, and $\left.{ }^{\mathrm{d}}<95 \%\right)$ evaluating bioeffects of nano- $\mathrm{ZnO}$ on the treated PBs in relation to the control PB; ${ }^{*}$ the values 0.5 and 1.0 represent the density of the bacterial suspension in the McFarland scale.

McFarland SBI, or only about $20 \%$ (i.e., from 0.15 up to $0.12 \times 10^{8} \mathrm{CFU} / \mathrm{ml}$ ) at using $0.5 \mathrm{McF}$ arland SBI.

Positive effect of $\mathrm{ZnO}$ nanoparticles reducing the growth activity of the molds Aspergillus niger and Penicillium brevicompactum on the top surfaces of $\mathrm{PBs}$ was unambiguous (Table 2). The growth activity of the P. brevicompactum significantly decreased from 2.33 up to 1.17 , that is, maximally about $49.8 \%$, and the growth activity of the $A$. niger significantly decreased from 2.67 up to 1.0 , that is, maximally about $62.6 \%$. These results are consistent with a low mold resistance of commercial untreated PBs [16], as well as with possibilities for improving their insufficient mold resistance by application of suitable fungicides [3, 49].

It is well known that fungicides based on $\mathrm{Zn}, \mathrm{Cu}$, and other heavy metals have a better efficiency against white-rot fungi compared to brown-rot fungi $[38,50]$. In spite of this fact, zinc oxide nanoparticles used in our experiment apparently improved the resistance of PBs against the brown-rot fungus Coniophora puteana, since weight losses of nano-ZnO-treated PBs significantly decreased from $17.38 \%$ up to $2.48 \%$, that is, maximally about $85.7 \%$ (Table 2; Figures 1 and 2). Weight losses of PBs, caused by the activity of this decaying fungus, reduced exponentially in accordance with a higher content of nano- $\mathrm{ZnO}$ in MUF glues: $\Delta m=3.02$ $+\exp \left(2.66-0.24 \times w_{(\mathrm{ZnO})} / w_{(\mathrm{MUF})}\right)$ (Figure 1). Similarly, Marzbani et al. [24] determined for PBs bonded with nano$\mathrm{ZnO}$-modified MUF glues an exponential decrease of their weight losses at action of C. puteana and also at action of the white-rot fungus Trametes versicolor.

Biological resistance of chemically preserved PBs depends on more factors, among which the most dominant are the three ones: (1) the kind and amount of biocides; (2) the type and amount of wood particles, glues, waxes, and other additives; and (3) the macro- and microdistribution of biocides, for example, which is dependent on the production technology of PB. However, in practice, environmental conditions and leaching or evaporation of biocides from preserved PBs cannot be neglected [51, 52].

Treatment of wooden composites with biocides was studied by several researchers. For example, Stangierska et al. [3] found that PBs can be completely protected from damage by the brown-rot fungus Coniophora puteana with organic fungicides (a mixture of didecyldimethylammonium

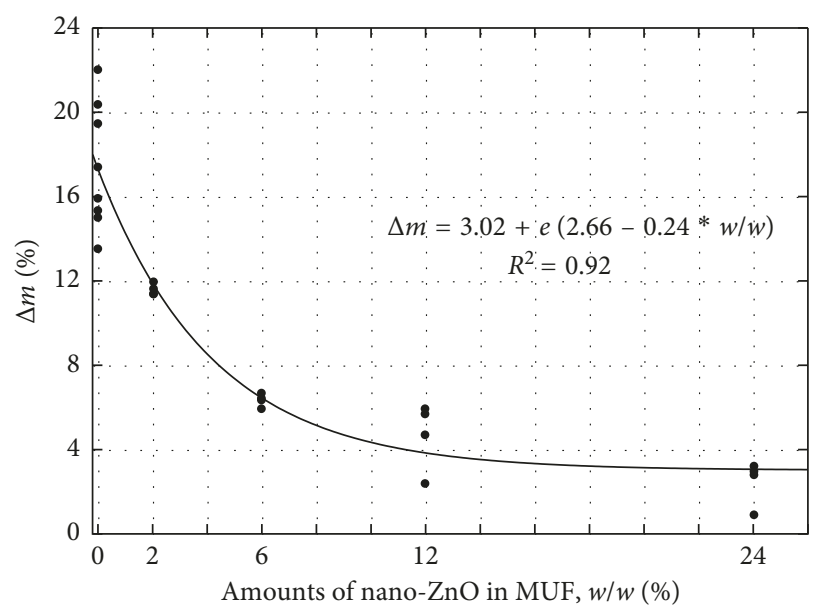

Figure 1: Exponential correlation between a higher content of nano-ZnO in MUF glue $(w / w, \%)$ used in the production of PBs and a smaller weight loss $(\Delta m, \%)$ of the nano-ZnO-treated PBs exposed to the attack by the brown-rot fungus Coniophora puteana.

nitrate and 1,2,4-triazole derivative in amount of $3.0 \mathrm{~kg}$ per $\mathrm{m}^{3}$ of PB in amino glues). Bayatkashkoli et al. [53] showed that the highest biological resistance of $\mathrm{PBs}$ against termites was obtained by addition of BFCA (boron-fluorinechromium-arsenic) or ACQ (alkaline copper quaternary). Sen et al. [54], on testing composites, which have been made from recycled carton, wood veneers, and four glue types, found that the most resistant composite against the fungus C. puteana was the one prepared with MUF glue. Evans et al. [55] on visualizing the microdistribution of zinc borate in OSBs with X-ray microcomputed tomography and SEMEDX pointed out that nonuniform concentration and nonhomogeneous distribution of this biocide may lead to a partial damage of final composite boards by fungi.

Biocidal effect of nano- $\mathrm{ZnO}$ on bacteria, molds, and decaying fungi is usually explained by its direct impact on these organisms. He et al. [56] on examining the efficacy of nano- $\mathrm{ZnO}$ on the fungus Botrytis cinerea with Raman spectroscopy found that this biocide significantly increased the content of nucleic acid and carbohydrate groups, but no significant change occurred in protein and fat groups. Differences in the spectrum were confirmed by principal 


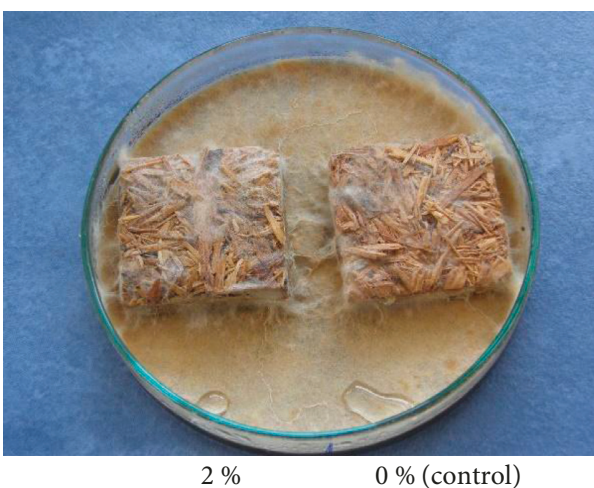

(a)

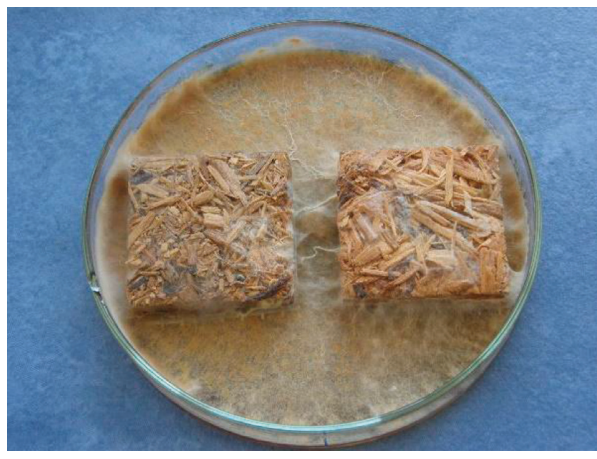

$12 \%$
$0 \%$ (control)

(c)

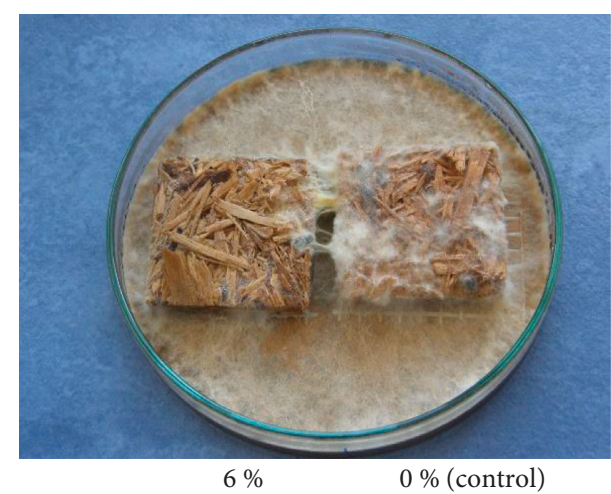

(b)

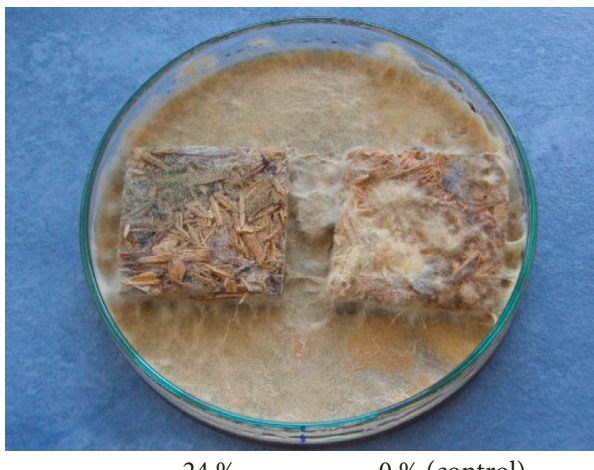

$24 \%$

(d)

FIgure 2: Growth of the surface mycelia of the brown-rot fungus Coniophora puteana on the top surfaces of the nano-ZnO-treated PBs (prepared by MUF glues modified by addition of 2, 6, 12, or 24\% wt. ZnO) and the control PB, after 6 weeks of the decay test.

TABLe 3: Physical and mechanical properties of the control PB and the nano-ZnO-treated PBs.

\begin{tabular}{|c|c|c|c|c|c|}
\hline \multirow{2}{*}{ Physical and mechanical properties of PBs } & \multicolumn{5}{|c|}{ Nano-ZnO (\% wt. in MUF glue) } \\
\hline & 0 & 2 & 6 & 12 & 24 \\
\hline Density $\left(\mathrm{kg} \cdot \mathrm{m}^{-3}\right)$ & $644(19.26)$ & $638(17.78)$ & $629(25.66)$ & $653(15.69)$ & $637(12.40)$ \\
\hline Thickness swelling (TS) after $2 \mathrm{~h}(\%)$ & $5.91(0.41)$ & $6.88(0.89)$ & $6.79(0.36)$ & $6.72(0.48)$ & $6.61(1.47)$ \\
\hline Thickness swelling (TS) after $24 \mathrm{~h}(\%)$ & $15.51(1.69)$ & $18.82(1.33)$ & $19.71(1.38)$ & $19.33(2.61)$ & $16.60(2.29)$ \\
\hline Water absorption (WA) after $2 \mathrm{~h}(\%)$ & $15.23(1.43)$ & $18.25(2.14)$ & $17.77(1.60)$ & $17.47(1.26)$ & $15.73(2.20)$ \\
\hline Water absorption (WA) after $24 \mathrm{~h}(\%)$ & $39.88(3.88)$ & $46.75(1.40)$ & $48.83(2.50)$ & $45.71(3.35)$ & $39.87(3.42)$ \\
\hline Internal bond (IB) strength $\left(\mathrm{N} \cdot \mathrm{mm}^{-2}\right)$ & $0.49(0.05)$ & $0.35(0.09)$ & $0.30(0.06)$ & $0.32(0.05)$ & $0.33(0.06)$ \\
\hline Bending strength (BS) $\left(\mathrm{N} \cdot \mathrm{mm}^{-2}\right)$ & $9.80(1.33)$ & $7.80(0.95)$ & $8.08(0.47)$ & $9.13(0.83)$ & $8.71(0.54)$ \\
\hline
\end{tabular}

Note. Mean values: density from 6 samples, TS from 8 samples, WA from 8 samples, IB from 10 samples, and BS from 6 samples. Standard deviations are in the parentheses.

component analysis (PCA). These results indicate that nucleic acids cause a stress response in the fungus mycelia. The growth of carbohydrates in the fungus can be explained by their excessive production in the defense mechanism of the fungus against zinc oxide nanoparticles $[57,58]$, at which excessive accumulation of nucleic acids and carbohydrates causes deformation of the cell structure in the fungus mycelia.

3.2. Application Properties of PBs. Selected physical and mechanical properties of the nano-ZnO-treated $\mathrm{PBs}$ are presented in Tables 3 and 4 and in Figure 3.
A higher proportion of zinc oxide nanoparticles in PBs did not have a more apparent tendentious effect on their density, thickness swelling after 2 or 24 hours, water absorption after 2 or 24 hours, and bending strength. This knowledge was for each of the above PBs property documented by almost the same mean value (Table 3 ) and also confirmed by minimal value of the coefficient of determination $R^{2}$ of linear correlation "Property $=a+b \times$ $\left(w_{\text {(ZnO) }} / w_{\text {(MUF) }}\right)$ " (Table 4$)$. On the other hand, interesting was an evident decrease of the internal bond at lower proportions of nano- $\mathrm{ZnO}$ in PBs (Tables 3 and 4; Figure 3). In summary, nano- $\mathrm{ZnO}$ in $\mathrm{PBs}$ manifested (1) as a neutral component from the point of view of its effect on their 
TABLE 4: Linear correlation analyses between the proportion of nano-ZnO in MUF glues $\left(x \rightarrow w_{(\mathrm{ZnO})} / w_{(\mathrm{MUF})}\right)$ and the selected properties of $\mathrm{PBs}$ containing nano-ZnO $(y)$.

\begin{tabular}{|c|c|c|c|c|c|c|}
\hline Properties of PBs & $n$ & $R$ & $R^{2}$ & $T$ & $P$ & $y=a+b \times x$ \\
\hline Density $\left(\mathrm{kg} \cdot \mathrm{m}^{-3}\right)$ & 30 & -0.03 & 0.00 & -0.16 & 0.88 & $641.3-0.06 \times w / w$ \\
\hline Thickness swelling after $2 \mathrm{~h}(\%)$ & 40 & 0.11 & 0.01 & 0.70 & 0.49 & $6.49+0.01 \times w / w$ \\
\hline Thickness swelling after $24 \mathrm{~h}(\%)$ & 40 & -0.05 & 0.00 & -0.32 & 0.75 & $18.12-0.01 \times w / w$ \\
\hline Water absorption after $2 \mathrm{~h}(\%)$ & 40 & -0.15 & 0.02 & -0.92 & 0.36 & $17.19-0.03 \times w / w$ \\
\hline Water absorption after $24 \mathrm{~h}(\%)$ & 40 & -0.27 & 0.07 & -1.70 & 0.10 & $45.47-0.14 \times w / w$ \\
\hline Internal bond strength $\left(\mathrm{N} \cdot \mathrm{mm}^{-2}\right)$ & 50 & -0.39 & 0.16 & -3.03 & 0.00 & $0.40-0.004 \times w / w$ \\
\hline Bending strength $\left(\mathrm{N} \cdot \mathrm{mm}^{-2}\right)$ & 30 & -0.13 & 0.02 & -0.79 & 0.43 & $9.03-0.02 \times w / w$ \\
\hline
\end{tabular}

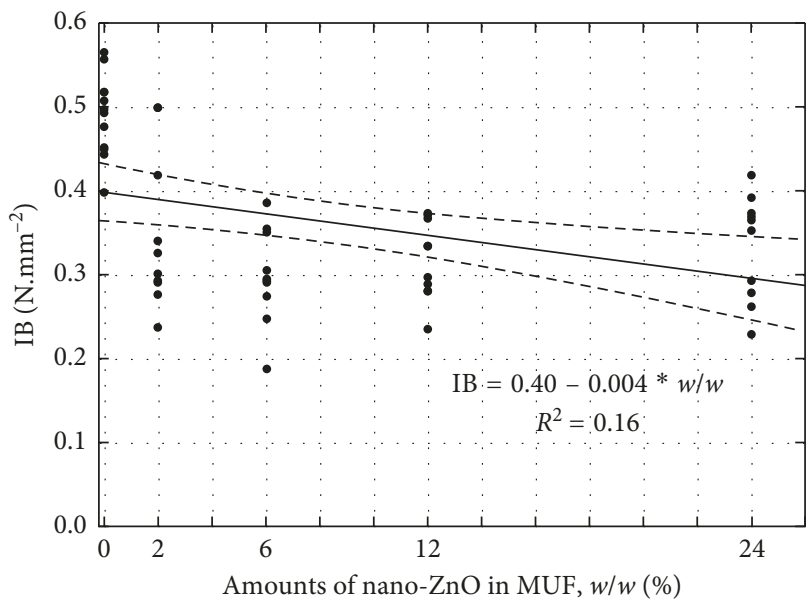

FIGURE 3: Linear correlation between a higher content of nano$\mathrm{ZnO}$ in MUF glue $(w / w, \%)$ used in the production of PBs and a reduced internal bond (IB) strength of the nano- $\mathrm{ZnO}$-treated $\mathrm{PBs}$.

moisture and bending properties and (2) as a negative component for their internal bond strength.

Iždinský and Reinprecht [59] founded that the traditional copper biocide "copper sulphate pentahydrate," applied in the same concentrations as in this work used nano- $\mathrm{ZnO}$, had a negative effect on some application properties of $\mathrm{PBs}$, that is, the thickness swelling increased by about $19.2 \%$ after 2 hours and by about $6.7 \%$ after 24 hours and the bending strength decreased by about $19.9 \%$. Bayatkashkoli et al. [53] found that the strength properties of $\mathrm{PBs}$ decreased or unchanged in the presence of other protective substances: BFCA, ACQ, or CTL (chlorothalonil). According to Guerreiro-Tanomaru et al. [60], nanoparticles of $\mathrm{ZnO}$ and $\mathrm{ZrO}_{2}$ added into Portland cement significantly decreased the compressive strength of silicate-based composite materials.

Rangavar and Hoseiny [61], on the contrary, showed that addition of copper biocides in a new form of nanoparticles into UF glue when manufacturing PBs from palm tree waste improved all their tested physical and mechanical properties. Similarly, according to Yingprasert et al. [62], PBs in the presence of some types of essential oils had better moisture properties (TS and WA); however, their mechanical properties were not affected, except a slight ca. 1.8\% reduction of the impact bending strength by cinnamon and clove oils.

In summary, environmental and application properties of wooden materials are more or less influenced by the type of glue, biocide, and other additives [63]. Some of these factors can also affect the adhesion forces on the phase interfaces "wood-glue" and subsequently the moisture and strength properties of wooden composites including PBs.

\section{Conclusions}

Nano-zinc oxide nanoparticles added into melamine-ureaformaldehyde (MUF) glue in the amounts of $0,2,6,12$, or $24 \%$ wt. produce the following phenomena:

(1) Increase the bioresistance of one-layer particleboards against

(a) the Gram-positive bacterium Staphylococcus aureus by up to ca. $72 \%$ and the Gram-negative bacterium Escherichia coli by up to $20-50 \%$;

(b) the molds Aspergillus niger and Penicillium brevicompactum by up to ca. $50-63 \%$;

(c) the brown-rot fungus Coniophora puteana by up to $85.7 \%$.

(2) Individual change or unchange the physical and mechanical properties of one-layer particleboards:
(a) unchange the density, thickness swelling, water absorption, and bending strength;
(b) decrease the internal bond strength by up to $38.8 \%$.

Generally, special particleboards bonded with MUF glues, and if necessary with addition of nano- $\mathrm{ZnO}$ as an ecologically friendly biocide, can be recommended for use in interiors with temporarily increased humidity, for example, for bathroom and kitchen cabinets which are occasionally exposed to bacterial and fungal risks.

\section{Conflicts of Interest}

The authors declare that they have no conflicts of interest.

\section{Acknowledgments}

This experimental work was supported by the Slovak Research and Development Agency under Contract no. APVV0200-12.

\section{References}

[1] Y. Imamura, "Estimation of the fungal resistance of wood composites for structural use," in Recent Research on Wood 
and Wood-Based Materials-Current Japanese Materials Research, N. Shiraishi, H. Kajita, and M. Norimoto, Eds., vol. 11, pp. 75-84, Elsevier, London, 2013.

[2] L. Reinprecht and V. Štefka, "Drevotrieskové dosky pojené močovinoformaldehydovým a fenolformaldehydovým lepidlom s prídavkom fungicídov," in Proceedings of the Pokroky vo výrobe a použití lepidiel v drevopriemysle (9th Symposium), pp. 227-238, Chemko Strážske, Czechoslovakia, 1989.

[3] A. Stangierska, J. Zabielska-Matejuk, and I. Frąckowiak, "The assessment of the resistance of particleboard protected with ionic liquids to Basidiomycetes and mould fungi," Annals of Warsaw University of Life Sciences-SGGW, Forestry and Wood Technology, vol. 84, pp. 190-193, 2013.

[4] A. N. Papadopoulos, "Mechanical properties and decay resistance of hornbeam cement bonded particleboards," Research Letters in Materials Science, vol. 2008, Article ID 379749, 4 pages, 2008.

[5] T. C. Chiang, S. Hamdan, and M. S. Osman, "Urea formaldehyde composites reinforced with sago fibres analysis by FTIR, TGA, and DSC," Advances in Materials Science and Engineering, vol. 2016, Article ID 5954636, 10 pages, 2016.

[6] M. J. Saad and I. Kamal, "Mechanical and physical properties of low density kenaf core particleboards bonded with different resins," Journal of Science and Technology, vol. 4, no. 1, pp. 17-32, 2012.

[7] H. R. Taghiyari and O. F. Bibalan, "Effects of copper nanoparticles on permeability, physical and mechanical properties of particleboard," European Journal of Wood and Wood Products, vol. 71, pp. 69-77, 2013.

[8] C. C. Tay, S. Hamdan, and M. S. B. Osman, "Properties of sago particleboards resinated with UF and PF resin," Advances in Materials Science and Engineering, vol. 2016, Article ID 5323890, 12 pages, 2016.

[9] European Committee for Standardization, EN 335: Durability of Wood and Wood-Based Products-Use Classes: Definitions, Application to Solid Wood and Wood-Based Products, European Committee for Standardization, Brussels, Belgium, 2013.

[10] T. Godish, Indoor Environmental Quality, Lewis Publisher, CRC Press LLC, Boca Raton, Florida, USA, 2001.

[11] J. W. Kirkpatrick and H. M. Barnes, "Biocide treatments for wood composites-a review," IRG/WP 06-40323, in Proceedings of the Paper prepared for the 37th Annual Meeting, pp. 1-21, Tromso, Norway, 2006.

[12] H. M. Barnes, "Durable composites: an overview," Processing of American Wood Protection Association, vol. 107, pp. 267-279, 2012.

[13] J. Ważny and A. Kundzewicz, "Conditions and possibilities of nanobiocides formulation for wood protection," DrewnoWood, vol. 51, no. 180, pp. 107-115, 2008.

[14] W. R. Smith and Q. Wu, "Durability improvement for structural wood composites through chemical treatment," Forest Products Journal, vol. 55, no. 2, pp. 8-17, 2005.

[15] European Committee for Standardization, EN 350: Durability of Wood and Wood-Based Products-Testing and Classification of the Durability to Biological Agents of Wood and WoodBased Materials, European Committee for Standardization, Brussels, Belgium, 2016.

[16] Z. Vidholdová, J. Iždinský, L. Reinprecht, and J. Krokošová, "Activity of bacteria and moulds on surfaces of commercial wooden composites," Materials Science Forum, vol. 818, pp. 190-193, 2015.

[17] W. D. Hanraman, L. J. Parlano, and I. W. Ong, "Antimicrobial melamine resin and products made therefrom," U. S. Patent 2006/0068662 A1, 2006.
[18] E. Nosál and L. Reinprecht, "Anti-bacterial and anti-mold efficiency of $\mathrm{ZnO}$ nanoparticles present in melaminelaminated surfaces of particleboards," BioResources, vol. 12, no. 4, pp. 7255-7267, 2017.

[19] J. Iždinský, L. Reinprecht, E. Nosál, Z. Vidholdová, and J. Krokošová, "The activity of bacteria on surfaces of wooden composites painted with acrylate coating with addition of silver nanoparticles," in Proceedings of the Wood Modification Research and Applications, (ModWoodLife) COST FP 1407 Conference, pp. 130-131, Kuchl, Salzburg, Austria, September 2017.

[20] R. J. Murphy, "Vapour phase treatments for wood products," in Wood Preservation in 90th and Beyond, Proceedings no. 7308, pp. 83-88, Forest Product Society, Madison, WI, USA, 1994.

[21] J. J. Morrell, M. N. Acda, and A. R. Zahora, "Performance of oriented strandboard, medium density fiberboard, plywood, and particleboard treated with tebuconazole in supercritical carbon dioxide," IRG/WP 05-30364, pp. 1-11, Bangalore, India, 2005.

[22] L. Reinprecht, Z. Vidholdová, and J. Iždinský, "Particleboards prepared with addition of copper sulphate-part 1: biological resistance," Acta Facultatis Xylologiae Zvolen, vol. 59, no. 2, pp. 53-60, 2017.

[23] L. Reinprecht and J. Perlác, "Properties of particleboards protected by TBTN and TCMTB fungicides," in Proceedings of the Wood modification '95 (10th Symposium), pp. 255-264, Poznaň, Poland, 1995.

[24] P. Marzbani, Y. M. Afrouzi, and A. Omidvar, "The effect of nano-zinc oxide on particleboard decay resistance," Maderas: Ciencia y tecnología, vol. 17, no. 1, pp. 63-68, 2015.

[25] European Committee for Standardization, EN 460: Durability of Wood and Wood-Based Products. Natural Durability of Solid Wood. Guide to the Durability Requirements for Wood to be Used in Hazard Classes, European Committee for Standardization, Brussels, Belgium, 1994.

[26] European Chemicals Agency, ECHA: Transitional Guidance on the Biocidal Products Regulation-Transitional Guidance on Efficacy Assessment for Product Type 8 Wood Preservatives, European Chemicals Agency, Helsinki, Finland, 2015.

[27] European Chemicals Agency, ECHA: Practical Guide on Biocidal Products Regulation, European Chemicals Agency, Helsinki, Finland, 2016.

[28] L. S. Mende and J. MacManus-Driscoll, " $\mathrm{ZnO}$ nanostructures, defects, and devices," Materials Today, vol. 10, no. 5, pp. 40-48, 2007.

[29] L. E. Shi, Z. H. Li, W. Zheng, Y. F. Zhao, Y. F. Jin, and Z. X. Tang, "Synthesis, antibacterial activity, antibacterial mechanism and food applications of $\mathrm{ZnO}$ nanoparticles: a review," Food Additives and Contaminants Part A, Chemistry, Analysis, Control, Exposure and Risk Assessment, vol. 31, no. 2, pp. 173-186, 2014.

[30] A. Sirelkhatim, S. Mahmud, A. Seeni et al., "Review on zinc oxide nanoparticles: antibacterial activity and toxicity mechanism," Nano-Micro Letters, vol. 7, no. 3, pp. 219-242, 2015.

[31] J. T. Seil and T. J. Webster, "Antimicrobial applications of nanotechnology: methods and literature," International Journal of Nanomedicine, vol. 7, pp. 2767-2781, 2012.

[32] K. R. Raghupathi, R. T. Koodali, and J. T. Manna, "Sizedependent bacterial growth inhibition and mechanism of antibacterial activity of zinc oxide nanoparticles," Langmuir, vol. 27, no. 7, pp. 4020-4028, 2011.

[33] C. Wang, L. L. Liu, A. T. Zhang, P. Xie, J. J. Lu, and X. T. Zou, "Antibacterial effects of zinc oxide nanoparticles on 
Escherichia coli K88," African Journal of Biotechnology, vol. 11, no. 44, pp. 10248-10254, 2012.

[34] S. Ghosh, R. G. Sankar, and V. Vandana, "Curious case of bactericidal action of ZnO," Journal of Nanoscience, vol. 2014, Article ID 343467, 8 pages, 2014.

[35] A. Stanković, M. Sezen, M. Milenković, S. Kaišarević, N. Andrić, and M. Stevanović, "PLGA/nano-ZnO composite particles for use in biomedical applications: preparation, characterization, and antimicrobial activity," Journal of Nanomaterials, vol. 2016, Article ID 9425289, 10 pages, 2016.

[36] A. Rezazadeh, M. R. M. Farahani, Y. M. Afrouzi, and A. A. D. Khalaji, "Investigation on rot resistance of Populus deltoides wood treated with nano-zinc oxide," World of Science Journal, vol. 2, no. 2, pp. 19-28, 2014.

[37] M. R. M. Farahani and F. Banikarim, "Effect of nano-zinc oxide on decay resistance of wood-plastic composites," BioResources, vol. 8, no. 4, pp. 5715-5720, 2013.

[38] G. Mantanis, E. Terzi, S. N. Kartal, and A. N. Papadopoulos, "Evaluation of mold, decay and termite resistance of pine wood treated with zinc- and copper-based nanocompounds," International Biodeterioration and Biodegradation, vol. 90, pp. 140-144, 2014.

[39] N. Bellotti, R. Romagnoli, C. Quintero, C. Domínguez-Wong, F. Ruiz, and C. Deyá, "Nanoparticles as antifungal additives for indoor water borne paints," Progress in Organic Coatings, vol. 86, pp. 33-40, 2015.

[40] L. Reinprecht, Z. Vidholdová, and M. Kožienka, "Inhibícia hniloby lipového dreva nanočasticami oxidu zinočnatého $\mathrm{v}$ kombinácii s akrylátom," Acta Facultatis Xylologiae Zvolen, vol. 57, no. 1, pp. 43-52, 2015.

[41] L. Reinprecht and Z. Vidholdová, "Growth inhibition of moulds on wood surfaces in presence of nano-zinc oxide and its combinations with polyacrylate and essential oils," Wood Research, vol. 62, no. 1, pp. 37-44, 2017.

[42] J. Iždinský, V. Tóth, and J. Kúdela, "Polyethylene terephthalate recycling in particle board production," in Wood the Best Material for Mankind, pp. 93-97, Arbora, Zvolen, Slovakia, 2013.

[43] European Committee for Standardization, EN 84: Wood Preservatives. Accelerated Ageing of Treated Wood prior to Biological Testing. Leaching Procedure, European Committee for Standardization, Brussels, Belgium, 1997.

[44] European Committee for Standardization, EN 15457: Paints and Varnishes-Laboratory Method for Testing the Efficacy of Film Preservatives in a Coating against Fungi, European Committee for Standardization, Brussels, Belgium, 2014.

[45] European Committee for Standardization, ENV 12038: Durability of Wood and Wood-Based Products-Wood-Based Panels-Method of Test for Determining the Resistance against Wood-Destroying Basidiomycetes, European Committee for Standardization, Brussels, Belgium, 2002.

[46] European Committee for Standardization, EN 317: Particleboards and Fibreboards: Determination of Swelling in Thickness after Immersion in Water, European Committee for Standardization, Brussels, Belgium, 1993.

[47] European Committee for Standardization, EN 319: Particleboards and Fibreboards: Determination of Tensile Strength Perpendicular to the Plane of the Board, European Committee for Standardization, Brussels, Belgium, 1993.

[48] European Committee for Standardization, EN 310: WoodBased Panels: Determination of Modulus of Elasticity in Bending and of Bending Strength, European Committee for Standardization, Brussels, Belgium, 1993.
[49] W. Y. Chung, S. G. Wi, H. J. Bae, and B. D. Park, "Microscopic observation of wood-based composites exposed to fungal deterioration," Journal of Wood Science, vol. 45, pp. 64-68, 1999.

[50] F. Green and C. A. Clausen, "Copper tolerance of brown rot fungi: oxalic acid production in southern pine treated with arsenic-free preservatives," International Biodeterioration \& Biodegradation, vol. 56, pp. 75-79, 2005.

[51] C. Tascioglu, K. Umemura, T. Yoshimura, and K. Tsunoda, "Biological performance of zinc borate-incorporated particleboard: effects of leaching on efficacy," Composites: Part B, vol. 57, pp. 31-34, 2014.

[52] C. Tascioglu, K. Umemura, S. S. Kusuma, and T. Yoshimura, "Potential utilization of sodium fluoride $(\mathrm{NaF})$ as a biocide in particleboard production," Journal of Wood Science, vol. 63, no. 6, pp. 652-657, 2017.

[53] A. Bayatkashkoli, B. Kameshki, S. Ravan, and M. Shamsian, "Comparing of performance of treated particleboard with alkaline copper quat, boron-fluorine-chromium-arsenic and chlorotalonil against Microcerotermes diversus and Anacanthotermes vagans termite," International Biodeterioration \& Biodegradation, vol. 120, pp. 186-191, 2017.

[54] S. Sen, N. Ayrilmis, and Z. Candan, "Fungicide and insecticide properties of cardboard panels made from used beverage carton with veneer overlay," African Journal of Agricultural Research, vol. 5, no. 2, pp. 159-165, 2010.

[55] P. D. Evans, V. Lube, H. Averdunk et al., "Visualizing the microdistribution of zinc borate in oriented strand board using X-ray microcomputed tomography and SEM-EDX," Journal of Composites, vol. 2015, Article ID 630905, 9 pages, 2015.

[56] L. He, Y. Liu, A. Mustapha, and M. Lin, "Antifungal activity of zinc oxide nanoparticles against Botrytis cinerea and Penicillium expansum," Microbiological Research, vol. 166, no. 3, pp. 207-215, 2011.

[57] F. J. Alvarez-Peral, O. Zaragoza, Y. Pedreno, and J. C. Argüelles, "Protective role of trehalose during severe oxidative stress caused by hydrogen peroxide and the adaptive oxidative stress response in Candida albicans," Microbiology, vol. 148, no. 8, pp. 2599-2606, 2002.

[58] K.-J. Kim, W. S. Sung, B. K. Suh et al., "Antifungal activity and mode of action of silver nano-particles on Candida albicans," Biometals, vol. 22, no. 2, pp. 235-242, 2009.

[59] J. Iždinský and L. Reinprecht, "Particleboards prepared with addition of copper sulphate-part 2: moisture and strength properties," Acta Facultatis Xylologiae Zvolen, vol. 59, no. 2, pp. 61-66, 2017.

[60] J. M. Guerreiro-Tanomaru, A. Trindade-Junior, B. C. Costa et al., "Effect of zirconium oxide and zinc oxide nanoparticles on physicochemical properties and antibiofilm activity of a calcium silicate-based material," Scientific World Journal, vol. 2014, Article ID 975213, 6 pages, 2014.

[61] H. Rangavar and M. S. F. Hoseiny, "The effect of nanocopper additions in a urea-formaldehyde adhesive on the physical and mechanical properties of particleboard manufactured from date palm waste," Mechanics of Composite Materials, vol. 51, pp. 119-126, 2015.

[62] W. Yingprasert, N. Matan, P. Chaowana, and N. Matan, "Fungal resistance and physico-mechanical properties of cinnamon oil- and clove oil-treated rubber-wood particleboards," Journal of Tropical Forest Science, vol. 27, no. 1, pp. 69-79, 2015.

[63] A. Pizzi, "Wood products and green chemistry," Annals of Forest Science, vol. 73, no. 1, pp. 185-203, 2016. 


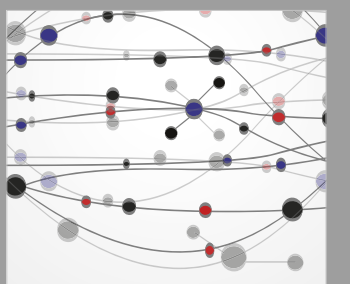

The Scientific World Journal
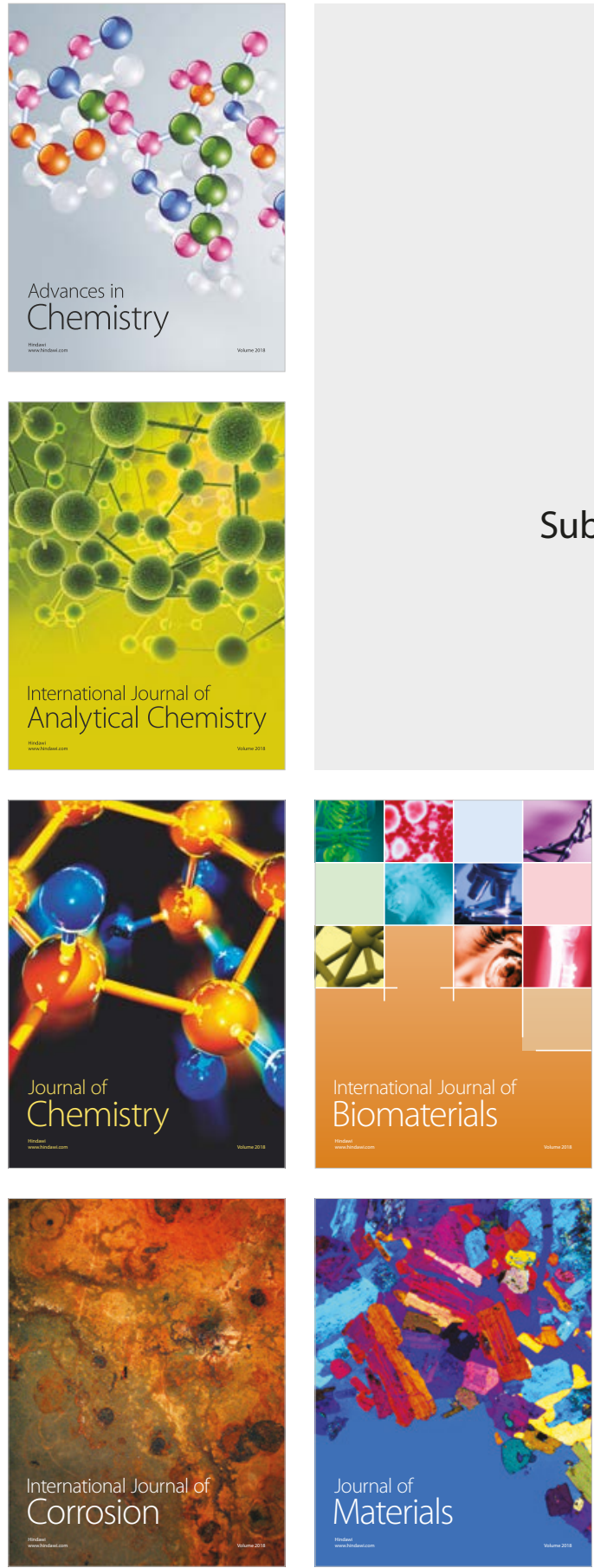

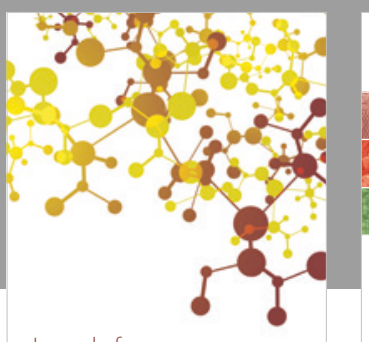

Journal of

Applied Chemistry
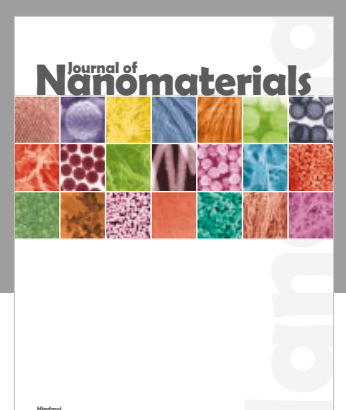

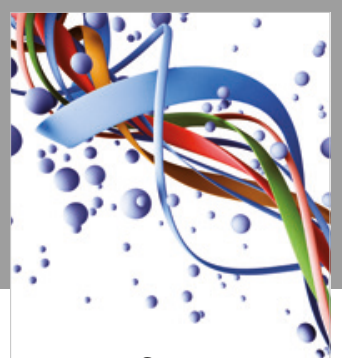

Scientifica

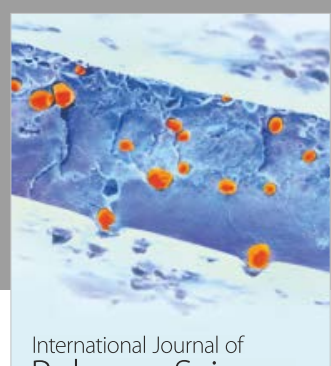

Polymer Science

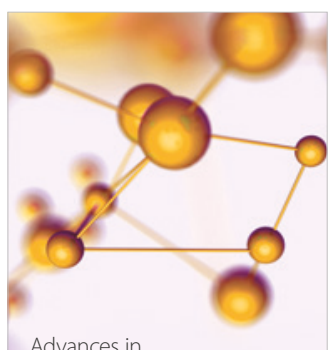

Physical Chemistry
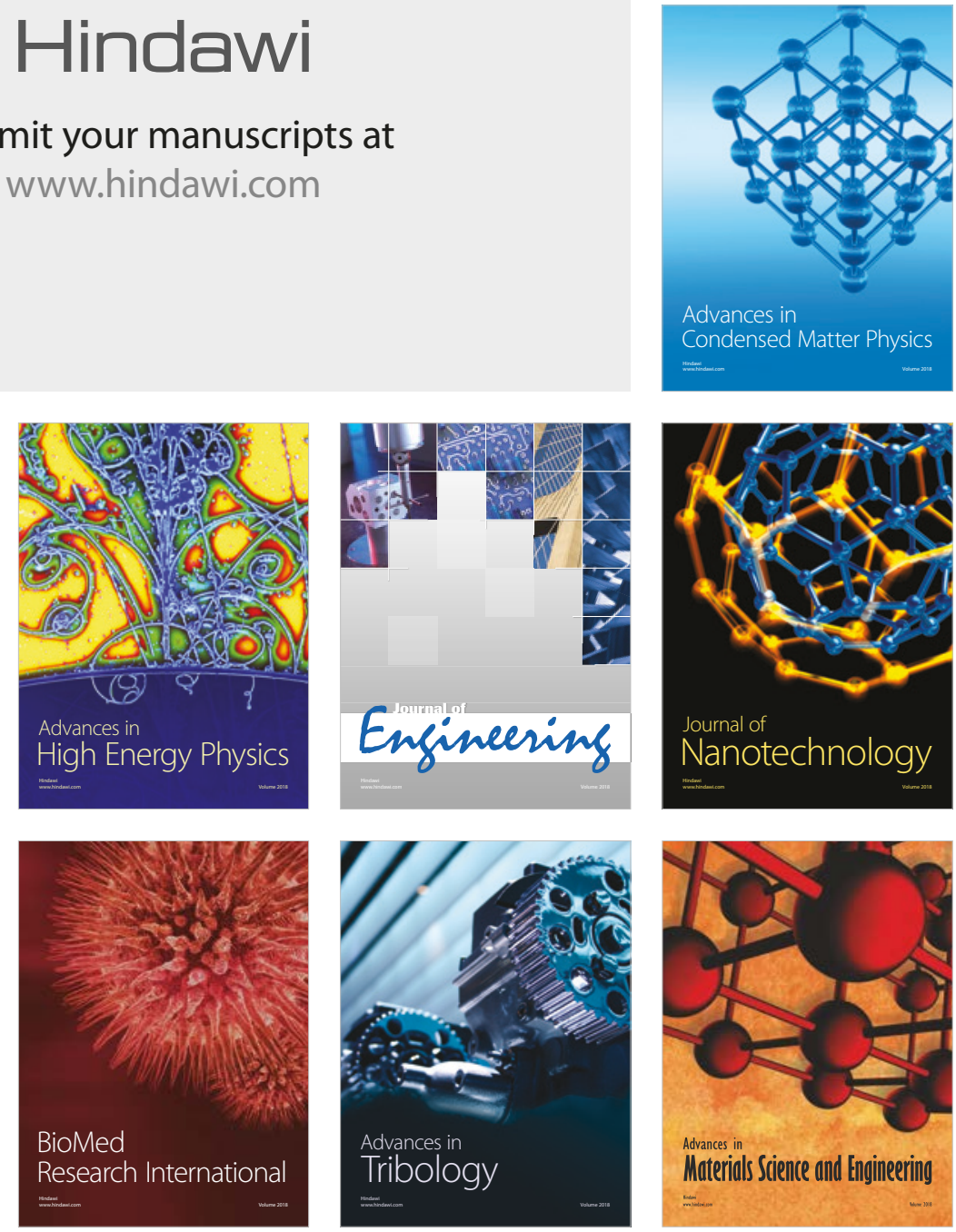